\title{
Ruling through Religion? Innovation and Tradition in Roman Imperial Representation
}

\author{
Olivier Hekster
}

The relation between men and gods was paramount in the Roman pagan world. Interactions between humans and the divine were the basis on which society was constructed. Where we have a tendency to differentiate between religion and politics, the Romans would not. Everything was potentially dependent on divine intervention. The absence of a single word for religion, was not caused by a lack of importance of the divine, but by its embeddedness in the Roman world. ${ }^{1}$ This of course impacted on the way in which exercising Roman power was conceived. Throughout Roman history, divine support was an unalienable part of political supremacy. How that support was expressed was much more flexible. There were very specific cases, like Sulla's highly individual 'divine luck,'2 but also a more general sense that 'the gods' needed to be behind any action for it to be successful. Bibulus' attempts to invalidate Caesar's consular legislation by watching for omens, for instance, was neither ridiculous nor unfounded. ${ }^{3}$ If the gods did not agree, surely they would make this clear. Bibulus' apparent popularity suggests that many Romans agreed that Caesar threatened the balance between men and gods, the oft-mentioned pax deorum. ${ }^{4}$

To rule in Rome, one needed the gods on one's side. There is even an argument to be made that ruling implied some sort of divine status. As argued by Ittai Gradel over fifteen years ago, worship in Rome was given to placate those who were of importance for the Roman State, whether man or god. Having power implied divine status; divinity was relative. The question, in Gradel's

1 The nearest term, religio, means firstly 'scrupulousness', secondly 'conscientiousness', and in third instance 'exactness'. All matters that are relevant to modern understanding of 'religion', but more or less tangentially. Only the fourth and fifth meaning, 'sanctity' and 'an object of worship', are firmly within our range of religious understanding. For the embeddedness of Roman religion, see especially Gasparini (2011) 260-99.

2 On Sulla and the construction and perception of his divine luck, see Eckert (2016) 43-85.

3 For Bibulus and other notions of 'sacred' obstruction in the Roman Republic, see De Libero (1992) 53-68.

4 E.g Scheid (2001) 25-6. For discussion, see still Linderski (1995) 6o8-25; 679. 
words, was not one of 'zoology', but of gradation within one 'species'. Caesar received temple, priest and the title of Divus Julius from the senate. These showed his supreme status. Whether that made him 'a god in an absolute sense' may be disputed, but it certainly put his power in a superhuman perspective. ${ }^{5}$ Beings with clear superior power were rapidly placed in a divine context. This also applied to Roman emperors, many of whom became 'official' gods after their deaths, some of whom claimed divine status during their life, and all of whom claimed an important role in the organization of Roman religion. In the eyes of many Roman subjects the situation may have been straightforward. Roman emperors, at least in the perception of most of these subjects, held absolute power in the greatest empire of the Mediterranean world. They were either gods themselves or supported by the gods.

Even if Roman rulers held superior status, they were not entirely free in their actions. Regular assassinations showed that there were bounds that were only crossed at severe risks. ${ }^{6}$ On the other hand, some rulers acquired such (posthumous) standing, that their behavior became exemplary - making it attractive to explicitly follow in their footsteps. Roman emperors were dependent on support from the various groups that constituted the Roman empire, and acting like a popular ruler boosted chances of a successful reign. Since, moreover, Roman emperorship was effectively a dynastic affair, rulers had to relate to the actions of their ancestors. ${ }^{7}$ This notion of 'exemplarity' was prominent in Rome: behavior and actions of noteworthy men became examples for other men to imitate, and norms by which other men were judged. ${ }^{8}$ Divine examples were often even better than historical ones, and it is striking how often intended changes in style of emperorship were presented as forms of following in the footsteps of specific gods or heroes. Commodus presenting himself as the new incarnation of Hercules comes to mind, as does Nero's close association to Apollo. ${ }^{9}$

In general, precedent was important in Rome, with continuous emphasis on the so-called mos maiorum (ancestral custom). Indeed, changes were occasionally blocked by referring to their innovative nature. In a famous edict from $302 \mathrm{CE}$ the emperors Diocletian and Maximian prohibited the 'new' religion of Manichaeism, by arguing that

5 Gradel (2002), esp. 26 and 72.

6 For a convenient overview, see Meijer (2004).

7 Hekster (2015) 320-1.

8 Roller (2004) 1-56; (2009) 214-30. See now Roller (2018).

9 Hekster (2002) 104-11, 117-29; Champlin (2003) 112-44. 
... the immortal gods, by their providence, deemed it worthy to ordain and to arrange that the things which are good and true would be approved and established in an undiminished state by the counsel and handling of many good and outstanding and very wise men, things which it is evil to obstruct or to resist, and that the old religion should not be refuted by a new belief. For it is the greatest crime to retract those things that, being set up and defined by the ancients, hold and possess standing and precedent. ${ }^{10}$

Similar edicts were issued against upcoming Christianity, to an extent using the same arguments. To counter such criticisms, literary, architectural and religious innovations were often presented as a return to ancestral customs, in order to make them more acceptable to Roman society.11

A good way of satisfying the mental framework which strongly emphasised a 'proper' ancestral way of doing things, was naming specific precedents. Pointing out that one followed actions of one of the exemplary figures in Roman history created a context in which behaviour became more acceptable.

This process can be usefully analysed by making use of the notion of 'anchoring'. This concept describes a subconscious phenomenon regarding the way in which people use cognitive footholds to adapt to new contexts. When confronted by something new, individuals start to think from (suggested) reference points or 'anchors', and then incrementally adjust their view by including additional information. These adjustments typically allow only limited distancing from the original anchor. ${ }^{12}$ This gives the initial anchor enormous influence over later perceptions. For instance, the use of the term princeps for the first Roman emperor Augustus, triggered Republican precedents in the mind of his subjects. This allowed emperorship to be more easily formulated in terms of the ancestral customs, and allowed the new political landscape to be more easily entrenched in Roman mentality. ${ }^{13}$

This volume focuses on popes and Peter, not on Roman emperors and pagan religion. Still, the two points raised so far in this article - the importance of

$10 \quad$ Mosaicarum et Romanarum Legum Collatio 15.3.3; translation Frakes (2012). The Diocletianic edicts against the Christians have not survived in their original forms, but can be reconstructed through the way they are described in ancient literature, noticeably the works of Eusebius.

11 See for an extended discussion on this point: Wallace-Hadrill (2008). Cf. Stark (2006) 1-30; Rives (2011) 265-80.

12 For the concept of anchoring, see Sluiter (2017) and http://www.ru.nl/oikos/anchoring -innovation/. For insufficient adjustment, see Tversky \& Kahneman (1974) 1124-31; 1128.

Hekster (2017a) 47-6o. Cf. Moatti (2011) 107-18. 
religious embeddedness in conceiving and constructing positions of power, and the importance of relevant anchors in a society dominated by tradition have direct relevance for Christianity as an upcoming religion, and for popes as increasingly defined leaders within that religion and in society as a whole. An obvious anchor for popes to use would turn out to be the figure of Peter though there were many alternatives, amongst whom Roman emperors. The extent to which the figure of Peter functioned as an anchor, and the connotations that his name and role brought to mind with different groups of Roman society at different times, is an underlying question within this volume. Peter would turn out to be an important figure to relate to, though his connotations could shift between time and place. Some of these shifts and modes in which Peter was viewed are at the center of subsequent articles. To illustrate how the concept of anchoring can help us to more fully understand the underlying processes, this paper will put forward two case studies, which aim to illustrate the bandwidth within which the contributions to this volume move.

The first case sketches some relevant developments of the title pontifex maximus, the importance of which is evident for any work on Peter. It is discussed in more detail in John Curran's contribution to this volume. The second case focuses on the different ways in which the emperor Constantine was linked to 'his' city of Constantinople, particularly as founder of the city. The close symbolic link between emperor and city forms a parallel to the importance of the city of Rome for the cult of Peter and may help us conceptualizing the process of memorialization of Peter at Rome.

On the Road to Power: Pontifex Maximus as Anchor for Supreme Status

Roman religion did not have a central authority. At the same time, it was recognized that the pontifices were the most eminent of the major priestly colleges. They formally supervised the religious life of the Roman state, and all matters not specifically assigned to other priesthoods fell to them. They made sure that nothing was done that could risk the pax deorum. The word pontifex is often translated as 'bridge builder', but a more likely origin is from the Etruscan pont (way/road) making the pontifices 'makers of way'.14 Though the meaning of the name is disputed, the role of the pontifices as mediators towards the divine was clear.

14 The meaning remains disputed. For an overview of the etymology: Van Haeperen (2002) 11-45; TLL, vol. X 1,2672, lin. 44-51, s.v. pontifex. 
Some antiquarian Roman texts argue that originally the college was led by the rex sacrorum. Yet, from early on, the most prominent position was that of the pontifex maximus, the elected leader of the pontifices. His roles, especially in adjudicating religious behavior, are discussed in John Curran's contribution to this volume. He was almost certainly the most powerful of the Roman priests. ${ }^{15}$ Considering the above-mentioned embeddedness of Roman religion, the line between a 'religious' priest and 'political' magistrate was impossible to draw in Roman times. Becoming a priest meant occupying a position of influence. Unlike almost all other such positions of influence in the Roman world, pontifex maximus was a position for life. That made it an attractive function for those with ambition, as became clear when Julius Caesar effectively wagered his career on being elected to the position. As Caesar's biographer, perhaps apocryphally, wrote down:

Thinking on the enormous debt which he had thus contracted, he is said to have declared to his mother on the morning of his election, as she kissed him when he was starting for the polls, that he would never return except as pontifex [maximus]. ${ }^{16}$

By getting himself elected to the pontificate, Caesar gained a prominent position in Rome. Occupying a traditionally important office improved his standing in society.

The situation was somewhat different for Caesar's adopted son Octavian, the later emperor Augustus. After the Battle of Actium in 31 BC, Octavian had effectively gained sole power over the Empire. Unlike Caesar, he did not need a traditional office to rise to prominence. Instead, he needed to explain his power in terms that his subject could understand and accept. Caesar had ultimately be killed by being too openly monarchical. His adoptive son would not make the same mistake. Already before $31 \mathrm{BC}$, he had started to position himself and his actions within a traditional Roman framework. Religion played an important role in that respect. In 31 BC, for instance, the war against Cleopatra was declared through the newly installed fetiales priests. Other priesthoods were likewise restored and transformed in the following years, as were 'some of the ancient rites which had gradually fallen into disuse'. For this period, too, the emperor stated to have restored eighty-two temples which were in need of

\footnotetext{
15 Festus 198.29-200.4; Gellius, NA 10.15.21; Servius. Aen. 2.2; Beard, North \& Price (1998) I, $55^{-9}$.

16 Suetonius, Caesar 13. Translation: Rolfe (LCL 38$)$.
} 
repair. ${ }^{17}$ Clearly, Augustus linked his power to divine support, as fitted a society so religiously embedded as Rome. In the same context, he also begun amassing positions within the four traditional priestly colleges, and emphasised these positions through, for instance, coinage. ${ }^{18}$

Augustus could not, however, claim the position of pontifex maximus. After Caesar's assassination, Lepidus had taken the role, and rather than killing the top ranking official for religious affairs, Augustus waited for him to die. ${ }^{19}$ When he did, in $12 \mathrm{BC}$, the emperor unsurprisingly became the new pontifex maximus. As shown by John Scheid, this marked a new moment in the emperor's 'religious policy'. Only now did he start to embark on a 'very real reform of Roman ritual tradition. ${ }^{20}$ Before, changing Roman religious practice would have been a sign of despotism. Now, it was anchored in his role of supervising the religious life of the Roman state.

The association that people have with specific anchors can, however, change over time. Augustus needed to anchor his actions in tradition, and the role of pontifex maximus was ideal for this. That role, however, would become one of the more recognizable parts of the honours and powers that were linked to emperorship. After Tiberius (a year after Augustus' death in $15 \mathrm{CE}$ ), Gaius, Claudius and Nero had become subsequent occupants of the position, the link between pontifex maximus and emperor was undeniable. ${ }^{21}$ John Curran rightly points out that for any emperor, 'the one title that more than any other signified his capacity to deal with res divinae was pontifex maximus'.22

Until the accession of Nerva in $96 \mathrm{CE}$, new emperors waited till the pontifical election in March to take up the role. From 96 onwards, the supreme pontificate had become so much part and parcel of the imperial office that the emperor took up the role on accession. The title and role was systematically emphasized in imperial statuary, inscriptions and coins. ${ }^{23}$ It was deemed so important, that the short-lived emperors Pupienus and Balbinus (reigning in $238 \mathrm{CE}$ ) both became pontifex maximus; a technical impossibility, but apparently an ideological necessity. ${ }^{24}$

\footnotetext{
17 Suetonius, Life of Augustus 31.3; RGDA 20.4; Hekster (2017) 54-5, with further references.

18 See, e.g. RIC I² Augustus 69 (nо. 367) (16 вс); 73 (nо. 410) (13 вС); already RSC no. 91 (37 BC).

19 Ridley (2005) 275-300.

20 Scheid (2005) 175-93; citation from 177.

$21 \quad$ Musiał (2014) 99-106.

22 Curran in this volume, p. 49.

23 Stepper (2003) 50; Cameron (2016) 139-59; 140; Manders (2012) 133-54.

24 Kienast $\left(2017^{6}\right) 183^{-5}$.
} 
The close link between emperorship and the title of pontifex maximus influenced people's association with the term. Where in Augustus' time, the emperor used the priesthood to anchor his actions in Republican precedent, by the third century, the title would make people think of Roman emperors in general, and Augustus in particular. ${ }^{25}$ With the growing influence of Christianity, there would be yet another new association. The title pontifex maximus would obtain pagan connotations. After Christianity had become the dominant and later official religion of the Empire, this double anchor - to imperial status and Rome's pagan past - would become complicated. Ultimately, it would lead Christian emperors to transforming the role. ${ }^{26}$ Notably, this was a transformation, not a repudiation of the position. The often-cited statement by Zosimus that Gratian $(367-383 \mathrm{CE})$ refused to wear the priestly garb because it was impious for a Christian to do so, was effectively countered by Alan Cameron's reference to an inscription from $369 \mathrm{CE}$ in which Valentinian, Valens and Gratian used pontifex maximus in their titulature. ${ }^{27}$

These rulers, like the later emperors Valentinian III (425-455) and Marcian (450-457), did present themselves in official documents as pontifex, but as pontifex inclitus, not Maximus; 'honourable' pontiff rather than the 'highest' one. Curran, in his contribution to the volume, discusses why matters came to a head when they did. For the purposes of this article, it is important to highlight that under Gratian there was a change of course, but not so extreme as is often assumed. The title of the supreme pontificate, apparently, brought with it too many connotations of the pagan past, and had become the wrong anchor for the purposes of imperial rule. Therefore, it was decided to change it into something that was new yet closely resembled the old in order to ensure a continuation of the religious authority of the emperor without offending the notoriously strong Roman sense of tradition.'. ${ }^{28}$ A new anchor was created, which was in itself linked (or anchored) to the earlier term. Connotations of terms shifted between time and place, and could be adjusted accordingly. After Christian emperors stopped using pontifex maximus in their names, the title would become even more closely linked to pagan emperorship. From the

25 Benoist (2009) 33-52; 43-7; Van Haeperen (2003) 137-59.

26 Cameron (2016) 144-7, returning to and extending some of the arguments in Cameron (2007) 341-84. See also Benétos (2017) 208-39; 229-32 for the importance of the title pontifex maximus for Constantine. Cf. Curran's contribution to this volume, section 3 in particular.

27 Zosimus, Historia Nova 4.36; ILS 771; Cameron (2016) 145. See now also Girardet (2018) and see also Curran in this volume, p. 5 .

28 Dijkstra \& Van Espelo (2017) 312-25; 313-8 for an overview of the recent discussion with full references. Citation from p. 316 . 


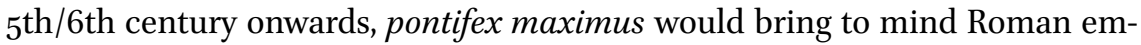
perors of old, not current rulers of the empire. This might explain why it would take such a long time for the title to be incorporated into papal nomenclature. ${ }^{29}$ Only when paganism was no longer a threat, connotations to pontifex maximus became wholly unproblematic. That did not necessarily make these connotations positive ones. For that, a re-evaluation of the value of antiquity was needed. Only in the fifteenth century were these requirements met to the extent that popes became pontifex maximus. To be the 'greatest pontiff' and forming a link to the increasingly appreciated classical past were now positive. That appropriation, finally, would yet again change people's association to the term, which became a papal, rather than an imperial term - implying direct succession from emperors to popes. ${ }^{30}$

\section{Constantine and Constantinople, Anchoring in Past and Future}

An office like the pontificate could change meaning over time in the eyes of Roman subjects. So could the associations with specific individuals. A relevant test case for the purposes of this volume may be the way the emperor Constantine was remembered in Constantinople. Clearly, Constantine's reputation as a whole is a subject that widely exceeds one section of a paper. ${ }^{31}$ Yet, like Peter, he is a towering individual who dominates early Christianity, and with whom a range of associations are possible. This makes him a useful figure to illustrate how the concept of anchoring may help us understand how changing memories and points of view influenced the connotations people had with a specific individual. For the purposes of this article, we will focus on changes in the way people linked Constantine to the city of Constantinople, which also effected (to an extent) the ways in which the emperor could be used as model for later Christian emperors, and may suggest a framework for ways in which Peter was memorialized in Rome. ${ }^{32}$

The link between the emperor Constantine and the later capital of the Roman empire was clear. The new city (formally Byzantion) not only carried his name, but was associated in many ways to the emperor who restored the unity of the Roman empire, and would be Rome's first Christian emperor. For the purposes of our argument, it is noticeable that Constantinople was in

\footnotetext{
29 Curran in this volume p. $5^{0 .}$

$30 \quad$ Van Haeperen (2003) 159; Dijkstra \& Van Espelo (2017) 320-5.

31 See, for instance, Van Dam (2011) 19-55.

32 Some of the issues in this paragraph have already been set out in Hekster (2011) 47-58.
} 
many ways a monument to the emperor's victory over Licinius at the Battle of Chrysopolis in September 324 CE. Much like Augustus founded Nicopolis to celebrate his Actium victory, so Constantine re-founded Byzantion as Nova Roma to celebrate the new unity of empire. In the process, he eradicated the memory of Licinius, whose imperial residence the city seems to have been. ${ }^{33}$ Similarly, Constantine had changed the meaning of many monuments in Rome with links to Maxentius. A number of buildings along the Via Sacra in Rome were reshaped (or simply renamed) in Constantine's name, and churches were built in locations that had been important to supporters of Maxentius. ${ }^{34}$

The monuments and churches in Rome functioned like different anchors in the public space to Constantine, making people think of the new emperor when moving about in the city. Equally, Byzantion became Constantinople, with a plurality of monuments reminding of the new founder. Not all of these monuments were in stone. Constantine also created a new Senate in Constantinople, making this new senate a marker of his influence. In the sole surviving letter of Constantine to the senate, for instance, he addressed it as 'his own senate (senatui suo)'. The possessive pronoun is telling. ${ }^{35}$ Even as traditional an institution as the senate could now remind people of the emperor. Physical monuments were even stronger anchors of imperial power. The palace, columns and statues must have dominated the city space. In Constantinople, furthermore, churches would function as a triple anchor: to the new emperor, to the god who supported him, and to the saints (such as the apostles) which the churches were dedicated to. These churches, furthermore, could act as symbols for Constantine's divine support - showing how the emperor guaranteed the pax deorum; much like he did as pontifex maximus.

Prime example was the Church of the Holy Apostles, constructed under Constantine just outside the city center. This building forms a clear indication how strongly the emperor aimed to position himself within Christian symbolism, at least towards the end of his life. The Church, as is clear, was dedicated to the twelve apostles. Although only a minor part of the eventual building was constructed under Constantine (a cross-shaped complex was erected under Constantius II), its lay-out and passages in Eusebius testify that the emperor wanted to be buried between the symbolic references to the apostles effectively becoming a thirteenth apostle. ${ }^{36}$

33 Stephenson (2009) 193 .

34 Drijvers (2007) 11-27; 26-7; Diefenbach (2007) 122-33.

35 Millar (1992) 354 n. 94. Cf. CIL 6.1873.

36 Eusebius, Vit. Const. 4.61-75, esp. 4.64; Mango (1990) 51-62; Dark \& Özgümüş (2002) 393-413. 
This notion of Constantine as apostle would not take hold. The EusebianConstantinian model of the emperor as a didaskalos (religious teacher), acting as a prophet or even apostle was fiercely argued against in fourth- and fifthcentury Christian literature. As ultimately set out by Ambrose of Milan, the emperor was 'son of the church, in the church and not above the church' (imperator ecclesiae filius ... intra ecclesiam non supra ecclesiam). ${ }^{37}$ What Constantine did reach, however, was a role as reference point for later Byzantine leaders and sainthood. Later emperors were hailed as 'new Constantines', with the eldest sons of new dynasties (Herakleios, Leo III, Leo V, Theophilos, Basil I) explicitly named after him. ${ }^{38}$ Constantine was an anchor conveying legitimacy, connected to the notion of a Christian continuation of the Roman empire.

Such an association became intrinsically linked to Constantine as founder of the new capital of the empire. Constantine was the new "first emperor" like Constantinople was the new Rome. Many images show Constantine as founder of the cities. This includes (near) contemporary pieces, like a fourth-century cameo from the Hermitage (figure 2.1), but also later ones, such as the famous mosaic from the Hagia Sophia (ca. $1000 \mathrm{CE}$ ), depicting Constantine holding a model of the city (figure 2.2).

Textual sources likewise stress the extent to which Constantine was seen as a founder of the city. More than any emperor was associated with Rome, mentioning Constantine seems to have brought his city to mind - and vice

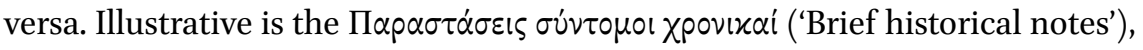
an overview of existing statues and monuments in Constantinople, dated to between 711 and 728 , and mentioning several buildings and statues that had been destroyed or lost by that stage. ${ }^{39}$ These notes show a Constantinople in decline, nostalgic for its heydays. Noticeably, Constantine had by then become a semi-legendary figure, in many ways akin to how Romulus was viewed in Late-Republican or Early-Imperial Rome. His presence in the cityscape was inescapable: the Notes name approximately 200 statues or statue groups by name, 40 of which are deemed to have depicted Constantine, with twelve statues of the emperor on the Forum alone ( $(15)$. There were statues of him at the S. Theodora, (§ 7), the Forum Tauri (§ 44a), the palatial tribunal $(\S 36)$, and in the Senate on the Forum ( $(43)$. In the Augusteum, there was an oversize statue of Constantine on a column, possibly the famous statue of Constantine as Sol. ${ }^{40}$

38 Dagron (2003) 149 with references; Magdalino (1994).

39 Cameron \& Herrin (1984).

$40 \quad \S 68,68$ a. Cf. $\S 10,23,38,56$. 


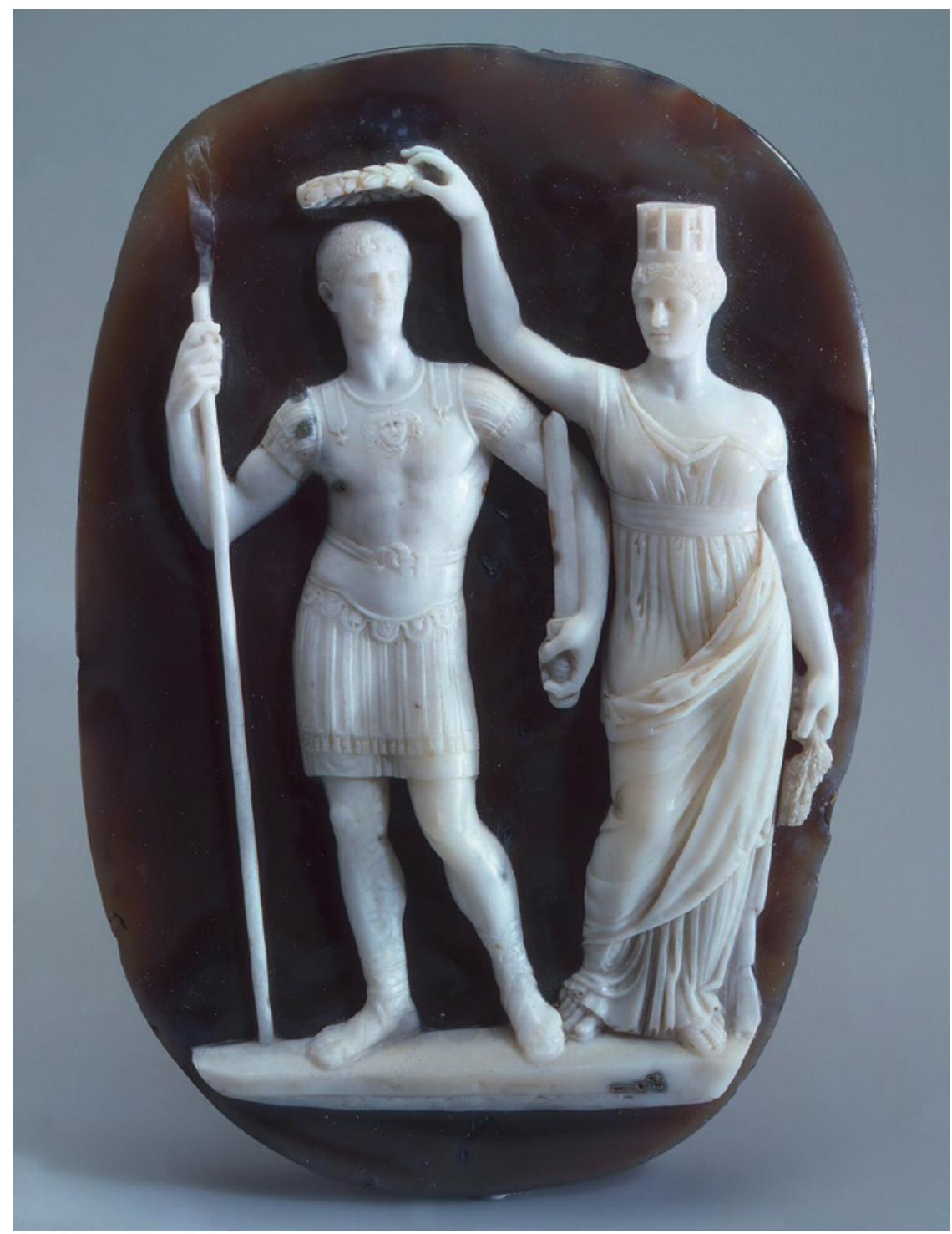

FIGURE 2.1 Sardonyx cameo of Constantine and the Tyche of Constantinople

But this statue, like other images of Constantine, was interpreted in a Christian context, with the foundation myth of the city explicitly retold as a battle be-

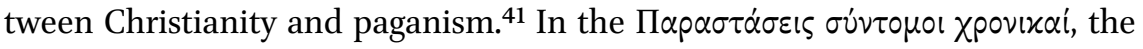

$41 \S 16, \S 39, \S 5^{2-59 .}$ 


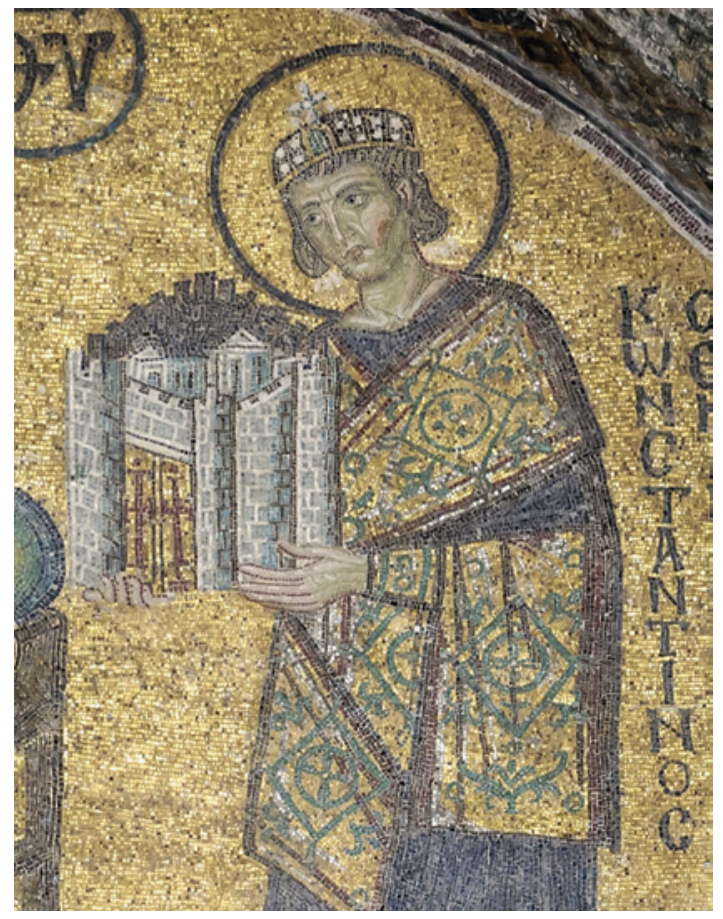

FIGURE 2.2

Mosaic in the southwestern entrance of the Hagia Sophia (Istanbul, Turkey)

countless statues of Constantine have become places of memory to a remote past; anchors to Constantine as Christian ruler, even making Sol a symbol of Christianity.

Doubtlessly, the many imperial 'new Constantines' helped to cultivate this image. The reputation of the original Constantine, after all, was the cognitive foothold from which their subjects started to think about the new rulers and dynasties. Since adjustments to that original anchor were typically limited, the status of Constantine as a model for good Christian emperorship made life easier for his explicit successors.

Concepts and reputations change meaning over time. That is not a new insight, nor one for which the concept of anchoring is necessary. But hopefully this article has given some indications as to how innovations can be placed in more traditional terms, by linking them to anchors; specific terms and individuals who trigger useful associations. Each time such an anchor is used, its associations may shift, with an increasingly intricate web of connotations. How that process played out surrounding the figure of Peter, and how he functioned as an ever-changing anchor for different groups at different times, is what this volume sets out to analyze. 


\section{Bibliography}

Beard, M., J. North \& S. Price. 1998. Religions of Rome I. Cambridge: Cambridge University Press.

Benétos, D. 2017. From divus Augustus to vicarius Christi: Examples of self-presentation in a period of transition. In Self-Presentation and Identity in the Roman World, ed. A. Gavrielatos, 229-32. Cambridge: Cambridge University Press.

Benoist, S. 2009. Du pontifex maximus à l'élu de dieu: l'empereur et les sacra ( $\mathrm{I}^{\mathrm{er}}$ s. av. n.e.- $\mathrm{V}^{\mathrm{e}} \mathrm{s}$. de n.e.). In Ritual Dynamics and Religious Change in the Roman Empire, ed. O. Hekster, S. Schmidt-Hofner \& C. Witschel, 33-52. Leiden/Boston: Brill.

Cameron, A. 2016. Pontifex maximus: from Augustus to Gratian - and beyond. In Emperors and the Divine - Rome and its Influence, ed. M. Kahlos, 139-59. Helsinki: Helsinki Collegium for Advanced Studies.

Cameron, A. 2007. The Imperial Pontifex. Harvard Studies in Classical Philology 103: 341-84.

Cameron, A. \& J. Herrin. 1984. Constantinople in the Early Eighth Century: the Parastaseis Syntomoi Chronikai. Introduction, Translation, and Commentary. Leiden/Boston: Brill.

Champlin, E. 2003. Nero. Cambridge (MA): Harvard University Press.

Dark, K. \& F. Özgümüş. 2002. New evidence for the Byzantine Church of the Holy Apostles from Fatih Camii, Istanbul, Oxford Journal of Archaeology 21:393-413.

DeLibero, L. 1992. Obstruktion:Politische Praktiken im Senatund in derVolksversammlung der ausgehenden römischen Republik (7o-49 v. Chr.). Stuttgart: Franz Steiner.

Dijkstra, R. \& D. van Espelo. 2017. Anchoring pontifical authority: A reconsideration of the papal employment of the title Pontifex maximus, JRH 41: 312-325.

Drijvers, J. W. 2007. Eusebius' Vita Constantini and the construction of the image of Maxentius. In From Rome to Constantinople. Studies in Honour of Averil Cameron, ed. H. Amirav \& B. ter Haar Romeny, 11-27. Leuven: Peeters.

Eckert, A. 2016. Lucius Cornelius Sulla in der antiken Erinnerung. Jener Mörder, der sich Felix nannte. Berlin/Boston: De Gruyter.

Frakes, R. M. 2012. Compiling the Collatio Legum Mosaicarum et Romanarum in Antiquity. Oxford: Oxford University Press.

Gasparini, V. 2011. Les cultes isiaques et les pouvoirs locaux en Italie. In Power, Politics and the Cults of Isis, ed. L. Bricault \& M. J. Versluys, 260-99. Leiden/Boston: Brill.

Girardet, K. M. 2018. Kaiser Gratian - letzter Träger von Amt und Titel eines pontifex maximus in der Geschichte des antiken Rom. RQA 113,3-4: 166-196.

Gradel, I. 2002. Emperor Worship and Roman Religion. Oxford: Oxford University Press. Hekster, O. 2002. Commodus. An Emperor at the Crossroads. Amsterdam: Gieben.

Hekster, O. 2011. Keizers en hun steden: Constantijn, Maxentius, Rome en Constantinopel. In Constantinopel: Een mozaïek van de Byzantijnse metropool, ed. D. Burgersdijk \& W. Waal, 47-58. Leiden: Ex Oriente Lux. 
Hekster, O. 2015. Emperors and Ancestors. Roman Rulers and the Constraints of Tradition. Oxford: Oxford University Press.

Hekster, O. 2017a. Identifying tradition. Augustus and the constraint of formulating sole rule. Politica Antica 7: 47-6o.

Kienast, D., W. Eck \& M. Heil. $2017^{6}$. Römische Kaisertabelle. Grundzüge einer römischen Kaiserchronologie. Darmstadt: Wissenschaftliche Buchgesellschaft.

Linderski, J. 1995. Roman religion in Livy. In Roman Questions. Selected papers, 608-25. Stuttgart: Franz Steiner.

Magdalino, P. 1994. New Constantines. The Rhythm of Imperial Renewal in Byzantium, 4th-13th Centuries. Aldershot: Ashgate.

Manders, E. 2012. Coining Images of Power: Patterns in the Representation of Roman Emperors on Imperial Coinage, AD 193-284. Leiden/Boston: Brill.

Mango, C. 1990. Constantine's mausoleum and the translation of relics, BZ 83:51-62.

Meijer, F. 2004. Emperors Don't Die in Bed (Or. title: Keizers sterven niet in bed). London/ New York: Routledge.

Millar, F. 20112. The Emperor in the Roman World, 31 BC-AD 337. New York: Cornell University Press.

Moatti, C. 2011. Historicité et altéronomie : un autre regard sur l'histoire, Politica antica 1: $107-118$.

Musiał, D. 2014. The princeps as Pontifex maximus: the case of Tiberius, Electrum 21: $99-106$.

Ridley, R. T. 2005. The absent Pontifex maximus, Historia 54: 275-300.

Rives, J. 2011. Religious choice and religious change in classical and late Antiquity: models and questions. Antigüedad, religiones y sociedades 9: 265-80.

Roller, M. 2004. Exemplarity in Roman culture: the cases of Horatius Cocles and Cloelia. Classical Philology 99: 1-56.

Roller, M. 2009. The exemplary past in Roman historiography and culture. In The Cambridge Companion to the Roman Historians, ed. A. Feldherr, 214-30. Cambridge: Cambridge University Press.

Roller, M. B. 2018. Models from the Past in Roman Culture. A World of Exempla. Cambridge: Cambridge University Press.

Scheid, J. 2005. Augustus and Roman religion: continuity, conservatism, and innovation. In The Cambridge Companion to the Age of Augustus, ed. K. Galinsky, 175-93. Cambridge: Cambridge University Press.

Scheid, J. 2001. Religion et piété à Rome. Paris: Éditions La Découverte.

Sluiter, I. 2017. Anchoring Innovation: a classical research agenda. European Review 25(1): 20-38.

Stark, R. 2006. Religious competition and Roman piety. Interdisciplinary Journal of Research on Religion 2: 1-30.

Stephenson, P. 2009. Constantine: Unconquered Emperor, Christian Victor. London: Quercus. 
Stepper, R. 2003. Augustus et sacerdos. Untersuchungen zum römischen Kaiser als Priester. Stuttgart: Franz Steiner.

Tversky, A. \& D. Kahneman. 1974. Judgment under Uncertainty: Heuristics and Biases. Science 185: 1124-31.

Van Dam, R. 2011. Remembering Constantine at the Milvian Bridge. Cambridge/New York: Cambridge University Press.

Van Haeperen, F. 2002. Le collège pontifical (3 $3^{\text {ème }}$ s.a.C. $-4^{\text {ème }}$ s.p.C.). Bruxelles/Roma: $11-45$.

Van Haeperen, F. 2003. Des pontifes païens aux pontifes chrétiens. Transformations d'un titre : entre pouvoirs et représentations. $R B P h$ 81: 137-59.

Wallace-Hadrill, A. 2008. Rome's Cultural Revolution. Cambridge/New York: Cambridge University Press. 